\title{
Leiomyosarcoma of Deep Soft Tissue
}

National Cancer Institute

\section{Source}

National Cancer Institute. Leiomyosarcoma of Deep Soft Tissue. NCI Thesaurus. Code C121571.

A rare leiomyosarcoma that arises from the deep soft tissue in the retroperitoneum or abdominal cavity. 